\title{
IMPACT OF MAGNETIZATION AND SALINITY OF IRRIGATION WATER ON SOME SOIL PROPERTIES AND GROWTH OF WHEAT AND BARLEY
}

\author{
W.M. Omran \\ Department of Soil Science, Faculty of Agriculture, Menoufia University, Egypt.
}

Received: Aug. 29, 2017

Accepted: Sep. 16, 2017

\begin{abstract}
Because of the shortage of high quality irrigation water, using saline water in irrigation is the challenge, especially in desert lands. Magnetically treated water was introduced as an inexpensive and environmentally friendly technology to improve the value and usefulness of saline irrigation water. Wheat and barley are important cereal crops, which greatly affect Egyptian income. The research aims to test the effect of magnetized water on soil available water, chosen properties of soil and irrigation water, and the growth and nutrient content of barley and wheat irrigated with saline and non-saline water. A pot experiment was conducted to achieve the research objective. The results indicated significant beneficial effect of magnetized water on the soil available water. Moreover, magnetized water increased fresh and dry weight and nutrient content of plant. The study concluded that magnetized water reduced the harmful impact of salinity on soil and plant and recommended using magnetized water for the purpose of irrigating cereal crops grown in sandy soils, using both saline and non-saline water in irrigation.
\end{abstract}

Key words: Magnetized water - saline irrigation water - soil available water - nutrients wheat and barley growth.

\section{INTRODUCTION}

Sustainable agricultural development is controlled by water availability. As good quality water is scare, water of marginal quality has to be considered for use in agriculture. Using saline water in irrigation is the challenge, especially in desert lands. Magnetized water has been used in irrigation to improve the practical effectiveness of low quality water. Magnetized water is environmentally safe, cheap, and easy to use (Lihua and Jixun 2001, Carbonell et al. 2000, Cakmak et al. 2009, Maheshwari and Grewal 2009, Gholami and Sharafi 2010, Grewal and Maheshwari 2011, Omran et al. 2014, Rashidi et al. 2016). Wheat and barley are two winter cereal important crops in Egypt. They are different in their tolerance to irrigation water salinity. Wheat and barley are importance cereal crops, which greatly affect Egyptian income.

The research objective is to quantify the effect of magnetized water on soil available water and selected properties of soil and irrigation water and on the growth of wheat and barley irrigated with saline and nonsaline water in sandy soil.

\section{MATERIALS AND METHODS}

A pot experiment was conducted in winter of 2015, at the green house of the faculty of Agriculture Menoufia University, to study the effect of magnetization and salinity of irrigation water on wheat and barley growth and their content of nutrients and on some soil properties. The experiment was carried out in a complete randomized design with three replicate. The experimental soil was taken from the surface layer $(0-30 \mathrm{~cm})$ from a point close to the intersection of Cairo Alexandria desert road and El Alamen road (N30.561807; E30.260412). Each pot received $2 \mathrm{~kg}$ of air dried soil. Field capacity (FC), and permanent wilting point (PWP) were measured. Seeds of wheat (Triticum aestivum L.; CV. Suds 1) and barley (Hordeum vulgare L.; cv. Gustoe) of uniform 
size and shape without defects and malformation were selected. Full irrigation requirement $(100 \%$ of soil available water) was given to all pots with one irrigation interval (i.e. 4 days). Twenty five seeds per pot were sown and thinned to twenty seedlings. The magnetized water was obtained by passing tap water through the magnetic device. Magnetic treatment device, supplied by Magnetic Technologies L.L.C., model A 100, Russia, with $6 \mathrm{~m}^{3} / \mathrm{h}$ water flow, was used for magnetic treatment of tap water (Fig $1 \mathrm{~A}$ ). The magnetized device was adjusted using plastic parts (not affecting magnetization) to be suitable for its job and fitting a plastic tube and funnel to easily and simply passing the irrigation water (nonsaline and saline) and apply the further magnetically treated water to the pots (Fig 1 B).

Two small tanks for non-saline and saline water were employed to simulate normal case and the sequence technique in the open field. A plastic measuring flask and digital scale were used to apply irrigation requirements of treated and non-treated water.
Twenty four pots were employed in the experiment. Half of the pots, was cultivated with barley and the other half cultivated with wheat. Both of the pots of barley and wheat were further, divided into two equal groups: one group was irrigated with nonmagnetically treated water (Tap water) and the other group was irrigated with magnetically treated water. Each group was, also divided into two equal groups using non-saline and saline irrigation water (Tap water with $100 \mathrm{mM}$ of $\mathrm{NaCl}$ ).

Foliar complete mixture of Egyptian commercial fertilizer was given twice in equal dose to all pots. The chemical composition of the applied fertilizer was shown in Table 1.

The soil of the experimental study is loamy sand in texture (36.8\% coarse sand, $43.1 \%$ fine sand, $13.9 \%$ silt, and $6.2 \%$ clay) and with $\mathrm{pH}$ value 7.7 . Average soil salinity expressed as electrical conductivity (EC) was $1.9 \mathrm{ds} / \mathrm{m}$. The chemical analysis of the untreated irrigation water (tap water) indicated that $\mathrm{EC}$ was $0.09 \mathrm{ds} / \mathrm{m}$ and the $\mathrm{pH}$ value was 7 .

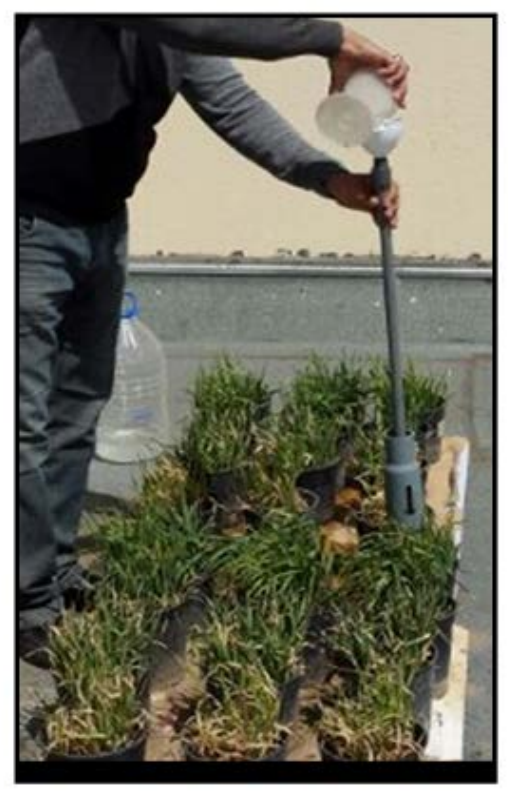

B

Fig 1: The magnetic device and the procedure to use it in irrigation 
Impact of magnetization and salinity of irrigation water on some soil .........

Table 1: Chemical decomposition of the applied fertilizer

\begin{tabular}{|c|c|c|c|}
\hline No & Component & Form & Concentration \\
\hline 1 & Nitrogen & $\mathrm{N}$ & $24 \%$ \\
\hline 2 & Phosphorus & $\mathrm{P}_{2} \mathrm{O}_{5}$ & $16 \%$ \\
\hline 3 & Potassium & $\mathrm{K}_{2} \mathrm{O}$ & $12 \%$ \\
\hline 4 & Magnesium & $\mathrm{MgO}$ & $1.5 \%$ \\
\hline 5 & Zinc & $\mathrm{Zn}$ & $0.05 \%$ \\
\hline 6 & Ferrous & $\mathrm{Fe}$ & $0.17 \%$ \\
\hline 7 & Manganese & $\mathrm{Mn}$ & $0.08 \%$ \\
\hline 8 & Cupper & $\mathrm{Cu}$ & $0.08 \%$ \\
\hline 9 & Boron & $\mathrm{B}$ & $640 \mathrm{ppm}$ \\
\hline 10 & \multicolumn{2}{|c|}{ Amino-acids } & $2 \%$ \\
\hline
\end{tabular}

Analyses of physical and chemical properties of the soil before (initial soil, IS) and after treatments (soil irrigated with tap water or experimental control, T). Particle size distribution, field capacity, permanent wilting point, available water, soil chemical analysis, and soil nutrient content, as well as water chemical analysis were conducted by the standard methods. Moreover, chosen properties of soil (i.e. cation exchange capacity; CEC and available macronutrients; NPK and some micronutrients; $\mathrm{Fe}, \mathrm{Cu}, \mathrm{Mn}$ and $\mathrm{Zn}$ ) were also determined.

After 75 days, from sowing, plants were harvested, and fresh and dry weight of both barley and wheat were recorded (i.e. average weight expressed as g/plant). Plants were digested and macronutrients (NPK) and some micronutrients $(\mathrm{Fe}, \mathrm{Cu}, \mathrm{Mn}$ and $\mathrm{Zn}$ ) in plants were determined. The performed procedures, methodology and analyses of soil and plant were conducted according to Ryan et al. (2001). Statistical analysis (Multivariate analysis and descriptive statistics) was done, to show the significance of its three studied factors (magnetization, salinity and crop type) on dependent concerned variables (e.g. soil, water and plant parameters), using the commercial computer program SPSS ver. 23. The statistical figures were executed using the commercial computer program STATISTICA ver. 12.

\section{RESULTS AND DISCUSSION \\ 1- Comparison between the properties of the initial soil (IS) (before treatment) and control treatment $(T)$ (soil irrigated with tap water)}

The comparison was done to ensure that the occurred changes of IS (if any) is due to the effect of treatments only or their combination with agricultural practices (e.g. cultivation, irrigation fertilization). Any significant differences between IS and $T$ should not interrupt the final data because the source of variation will be due to the agricultural practice effect, which is similar for all treatments.

As shown in Table 2, there is no significant differences between IS and T for the $\mathrm{pH}$ values. Whereas values of the soluble cations and anions, as well as, the 
CEC were significantly decreased, except the $\mathrm{SO}_{4}$ which significantly increased, under the treatment $T$ compaired with IS. These results may be due to the leaching action of the tap water (high quality water). The obtained results in Table 2 showed, also, significant increase, for all the macro and micro nutrients in the treatment $\mathrm{T}$ comparing with IS. Such result may be due to the fertilization application, which was given to all experimental pots as clarified in methodology section.

The measured soil field capacity (FC) and permanent wilting point (PWP) were 50.0 and $51.3 \%$ for the FC, and were 24.8 and $26.5 \%$ for the PWP, respectively for the IS and treatment $\mathrm{T}$. Then, the calculated soil available water (AW), for IS and T, was 25.2 and $24.8 \%$ respectively. There was no significant difference of AW between IS and $\mathrm{T}$.

\section{2- Effect of magnetization and salinity of irrigation water on soil properties}

2-1-Effect of magnetization and salinity of irrigation water on available water (AW).

AW values presented in Table 3 indicated significant increase with magnetization $(M)$, significant decrease with salinity (S), and significant effect of the interaction of $\mathrm{M}$ and $\mathrm{S}$. The data signpost that magnetized water did not significantly increase FC or PWP, while it significantly increased AW. This is may be due to that the calculated value is a measure to the integral effect of the magnetized water on the two points, which may magnifier the difference between FC and PWP (i.e. AW). Such result is very valuable, especially in deserts since it advantages irrigation interval increase, which reduce cost of labor and improve irrigation application efficiency due to the expected reduction of both evaporation and deep seepage. The obtained results agree with what was found by Hachicha (2016) who stated that magnetically treated water increased soil water retention. This is may be due to that magnetized water cause reduction of water surface tension and viscosity, while it increases water polarity (Mahmoud et al. 2011).

Presented results in Fig 2 insure positive effect of the magnetized water and negative effect of the water salinity on the amount of soil available water (AW). Furthermore, the same results indicate that magnetically treated water significantly diminished the harmful effect of salinity on AW. The appeared beneficial effect of the magnetization and the harmful effect of salinity may be due to that both magnetization and salinization affect soil water retention conversely. Magnetization enhanced water retention while salinity reduced it, especially with sodium ion. In this respect, Surendran et al. (2016) reported that: magnetized irrigation water caused higher soil moisture compared with the control for different solution of saline water.

Table 2: The properties of the initial soil (IS) (before treatment) and experimental control (T) (soil irrigated with tap water after treatment)

\begin{tabular}{|c|c|c|c|c|c|c|c|c|c|c|c|c|c|c|c|c|c|c|c|}
\hline \multirow{2}{*}{ Soil } & \multirow{2}{*}{$\begin{array}{c}\text { AW } \\
\%\end{array}$} & \multirow{2}{*}{$\mathrm{pH}$} & \multirow{2}{*}{$\begin{array}{l}\mathrm{EC}, \\
\mathrm{ds} / \mathrm{m}\end{array}$} & \multicolumn{8}{|c|}{ Soluble cations and anions (meq/l) } & \multirow{2}{*}{$\begin{array}{c}\text { CEC } \\
\text { meq/ } \\
100 \mathrm{~g} \\
\text { soil }\end{array}$} & \multicolumn{7}{|c|}{$\begin{array}{l}\text { Available nutrients ( } \mathrm{mg} / \mathrm{Kg} \\
\text { Soil) }\end{array}$} \\
\hline & & & & $\mathrm{CO}_{3}$ & $\mathrm{HCO}_{3}$ & $\mathrm{Cl}$ & $\mathrm{SO}_{4}$ & $\mathrm{Ca}$ & $\mathrm{Mg}$ & $\mathrm{Na}$ & K & & $\mathrm{N}$ & $\mathrm{P}$ & K & $\mathrm{Fe}$ & $\mathrm{Cu}$ & $\mathrm{Mn}$ & $\mathrm{Zn}$ \\
\hline IS & 25 & 8 & 1.9 & 0 & 2.9 & 35 & 13 & 24 & 9 & 14 & 4 & 15 & \#\# & 2 & 81 & 1 & 1 & 1 & 1 \\
\hline $\mathrm{T}$ & 25 & 8 & 1.4 & 0 & 2.2 & 27 & 16 & 22 & 8 & 10 & 4 & 14 & $\# \#$ & 4 & $\# \#$ & 2 & 1 & 2 & 1 \\
\hline $\begin{array}{c}\text { F- } \\
\text { test }\end{array}$ & NS & NS & $\star \star$ & $\star \star *$ & $\star *$ & $\star \star$ & $\star \star \star$ & $\star \star$ & $\star \star$ & $\star \star$ & ** & $\star *$ & $\star *$ & $\star *$ & $\star \star$ & ** & $\star \star$ & $\star *$ & * \\
\hline
\end{tabular}

AW=Soil Available Water, NS=Not Significant, ${ }^{*}=$ Significant at $p<0.05,{ }^{* *}=$ Significant at $p<0.02$. 
Impact of magnetization and salinity of irrigation water on some soil .........

Table 3: Soil FC, PWP and AW as affected by treatments

\begin{tabular}{|c|c|c|c|c|c|c|}
\hline $\begin{array}{c}\text { Parameter } \\
\text { Treatment }\end{array}$ & FC & F-test & PWP & F-test & AW & F-test \\
\hline T & $50.97 \pm 2.64$ & & $26.06 \pm 1.39$ & & $24.90 \pm 1.45$ & \\
\hline M & $53.70 \pm 2.94$ & NS & $25.80 \pm 1.41$ & NS & $27.90 \pm 1.53$ & $*$ \\
\hline S & $42.50 \pm 2.33$ & $* \star$ & $23.00 \pm 1.26$ & $* \star$ & $19.50 \pm 1.07$ & $* *$ \\
\hline $\mathrm{M} \times \mathrm{S}$ & $47.17 \pm 1.39$ & NS & $24.12 \pm 0.72$ & NS & $23.05 \pm 0.71$ & $*$ \\
\hline
\end{tabular}

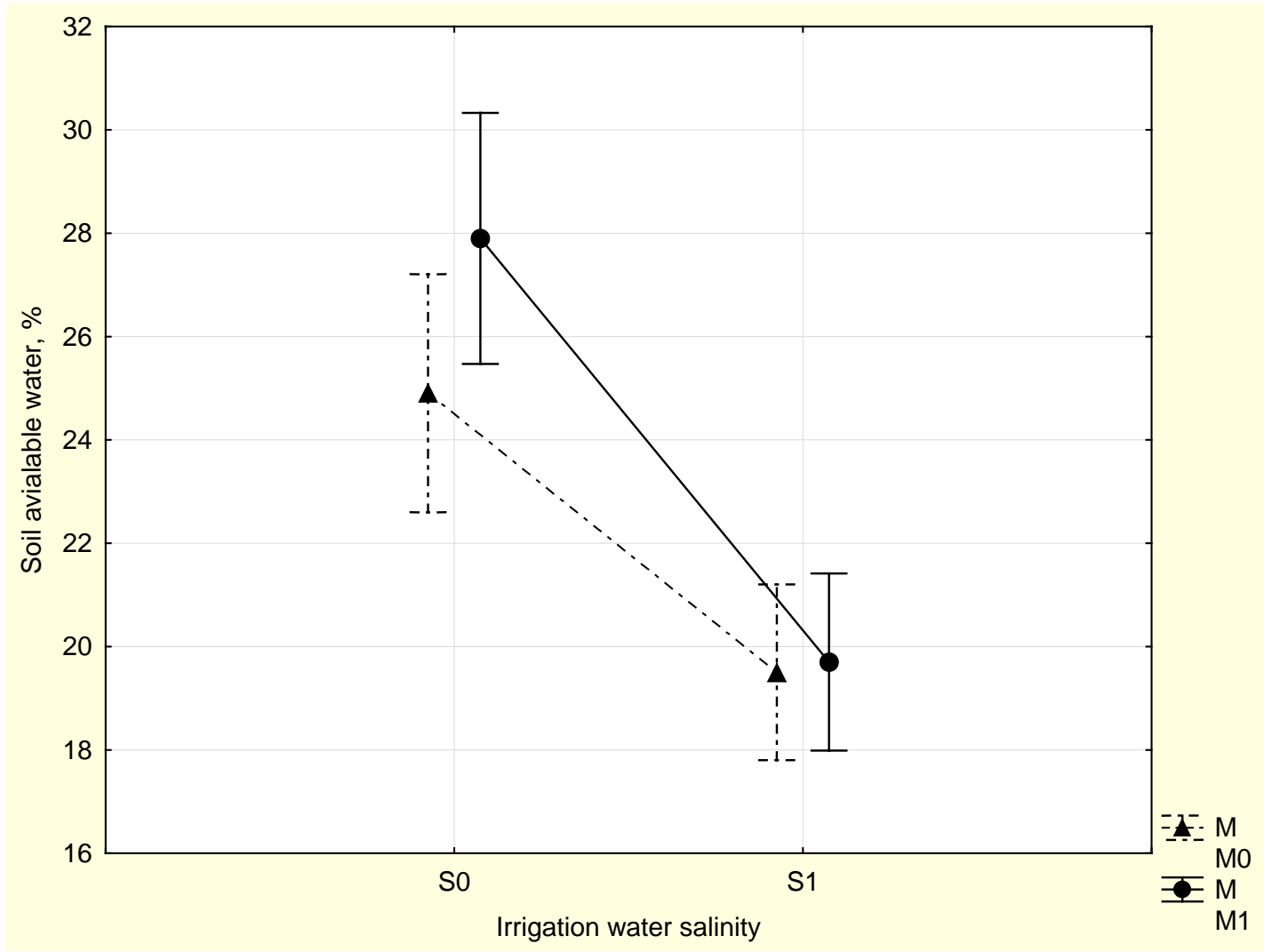

(M0 = non magnetized; $\mathrm{M} 1$ = magnetically treated; S0 non-saline; S1 saline)

Fig 2: Effect of the magnetization and salinity of the irrigation water on soil AW

\section{2-2-Effect of magnetization and salinity of irrigation water on soil chemical analysis}

Table 4 indicates that magnetized water significantly decreased $\mathrm{Cl}, \mathrm{SO}_{4}, \mathrm{Na}, \mathrm{K}$, and CEC under non-saline irrigation water, while increased their values under saline irrigation water. Significant increase of $\mathrm{Mg}$ was observed of both non-saline and saline water. Magnetized water did not show significant effect on other soil chemical analysis parameters. The results, also, revealed significant effect of salinity on all studied parameters except $\mathrm{pH}$ and CEC. The remarkable observation is the significant effect of the interaction of magnetization and salinity of experimental studied parameters except $\mathrm{pH}$ and $\mathrm{Ca}$. The obtained result agrees with the results of Surendran et al. (2016), who found that Magnetic treatments reduced dissolved solids and not affect $\mathrm{pH}$. 
Table 4: Average values of the soil chemical parameters

\begin{tabular}{|c|c|c|c|c|c|c|c|c|c|c|}
\hline $\begin{array}{c}\text { Parameter } \\
\text { Treatment }\end{array}$ & $\mathrm{pH}$ & $\mathrm{EC}$ & $\mathrm{HCO}$ & $\mathrm{Cl}$ & $\mathrm{SO} 4$ & $\mathrm{Ca}$ & $\mathrm{Mg}$ & $\mathrm{Na}$ & $\mathrm{K}$ & $\mathrm{CEC}$ \\
\hline $\mathrm{T}$ & $\begin{array}{c}7.6 \\
\pm 0.21\end{array}$ & $\begin{array}{c}1.4 \\
\pm 0.04\end{array}$ & $\begin{array}{c}2.2 \\
\pm 0.06\end{array}$ & $\begin{array}{c}26.7 \\
\pm 0.79\end{array}$ & $\begin{array}{c}15.6 \\
\pm 0.46\end{array}$ & $\begin{array}{c}22.3 \\
\pm 0.66\end{array}$ & $\begin{array}{c}8.2 \\
\pm 0.24\end{array}$ & $\begin{array}{c}10.0 \\
\pm 0.29\end{array}$ & $\begin{array}{c}4.0 \\
\pm 0.12\end{array}$ & $\begin{array}{c}14.4 \\
\pm 0.42\end{array}$ \\
\hline $\mathrm{M}$ & $\begin{array}{c}7.4 \\
\pm 0.22\end{array}$ & $\begin{array}{c}1.1 \\
\pm 0.03\end{array}$ & $\begin{array}{c}2.0 \\
\pm 0.06\end{array}$ & $\begin{array}{c}23.6 \\
\pm 0.69\end{array}$ & $\begin{array}{c}11.8 \\
\pm 0.35\end{array}$ & $\begin{array}{c}20.0 \\
\pm 0.59\end{array}$ & $\begin{array}{c}9.2 \\
\pm 0.27\end{array}$ & $\begin{array}{c}4.6 \pm \\
0.14\end{array}$ & $\begin{array}{c}3.6 \\
\pm 0.11\end{array}$ & $\begin{array}{c}12.0 \pm \\
0.35\end{array}$ \\
\hline $\mathrm{S}$ & $\begin{array}{c}7.5 \\
\pm 0.25\end{array}$ & $\begin{array}{c}6.8 \\
\pm 0.20\end{array}$ & $\begin{array}{c}2.8 \\
\pm 0.08\end{array}$ & $\begin{array}{c}73.7 \\
\pm 2.17\end{array}$ & $\begin{array}{c}34.8 \\
\pm 1.02\end{array}$ & $\begin{array}{c}36.1 \\
\pm 1.06\end{array}$ & $\begin{array}{c}22.2 \\
\pm 0.65\end{array}$ & $\begin{array}{c}48.2 \\
\pm 1.42\end{array}$ & $\begin{array}{c}4.8 \\
\pm 0.14\end{array}$ & $\begin{array}{c}12.6 \\
\pm 0.37\end{array}$ \\
\hline $\mathrm{M} \times \mathrm{S}$ & 7.5 & 4.1 & 2.5 & 53.0 & 24.8 & 28.9 & 18.7 & 28.5 & 4.1 & 13.2 \\
\hline F-test for M & $\mathrm{NS}$ & $\mathrm{NS}$ & $\mathrm{NS}$ & $* *$ & $*$ & $\mathrm{NS}$ & $* *$ & $*$ & $* *$ & $* *$ \\
\hline F-test for S & $\mathrm{NS}$ & $* *$ & $* *$ & $* *$ & $* *$ & $* *$ & $* *$ & $* *$ & $* *$ & NS \\
\hline F-test for M×S & $\mathrm{NS}$ & $* *$ & $* *$ & $* *$ & $* *$ & $* *$ & $* *$ & $* *$ & $* *$ & $* *$ \\
\hline
\end{tabular}

\section{2-3- Effect of magnetization and salinity of irrigation water on soil content of nutrients}

The obtained results for the available nutrients and its statistical analysis in Table (5) elucidate a significant beneficial effect of magnetized water (M) on promoting available soil content of $\mathrm{N}$ and $\mathrm{K}$. On the other hand, the results manifest a significant reduction effect on the available soil content of $\mathrm{Fe}, \mathrm{Cu}$, and $\mathrm{Mn}$. No significant effect of irrigation water salinity on all studied nutrients except Zn. Significant increase of K was observed for the interaction effect of magnetization and salinity. The results, also, significantly affect $\mathrm{Fe}, \mathrm{Mn}$, and Ze. Generally, the results manifest a promotion impact of magnetized water on macronutrients and did not have specific trend for micronutrients. The obtained results may be due to that micronutrients are minor in the soil, which may cause misleading. The plant growth and nutrient content may be more reliable in evaluating the effect of both magnetization and salinization of irrigation water.

\section{3- Effect of magnetization and salinity on irrigation water chemical analysis}

The data of Table 6 indicates a significant effect of magnetized water on all studied parameters except $\mathrm{Cl}$ and $\mathrm{Na}$. Also, there was a significant effect of the salinity of the irrigation water on all studied parameters. In addition, there was significant effect of the interaction between magnetization and salinity of all studied parameters except $\mathrm{pH}, \mathrm{Cl}, \mathrm{Ca}, \mathrm{Mg}$ and $\mathrm{Na}$.

Although, the significant effect of magnetization and salinization on the chemical analysis of the tap water, the results may be misrepresentative, because tap water contains only traces of the measured soluble elements. Furthermore, under saline water, both $\mathrm{Cl}$ and $\mathrm{Na}$ were not significantly affected by magnetization or its interaction with salinity, while they were affected by salinization (i.e. $100 \mathrm{mM}$ of $\mathrm{NaCl}$ addition), which insure different trend with higher concentration elements.

4- Effect of magnetization and salinity of irrigation water on plant (wheat and barley)

4-1 Fresh weight (FW) and dry weight (DW) of wheat and barley (g/pant)

There was significant difference between barley and wheat in their FW and DW 
regardless salinity or magnetization of irrigation water, when the statistical analysis was done for the all three studied factors at one time (i.e. three way ANOVA). No significant effect was indicated, of the two factors interaction ( $\mathrm{M} \times \mathrm{S}$ or $\mathrm{M} \times$ Crop Type) or triple interaction $(\mathrm{M} \times \mathrm{S} \times$ Crop Type). The only significant effect was observed of the two factors interaction, $\mathrm{S} \times$ Crop Type, on DW only. The only important result of such kind of statistical analysis is that it insures significant difference between wheat and barley in their tolerance to salinity (barley was more tolerant to salinity than wheat), which is not the objective of the research. The disadvantage of this technique of statistical analysis is that it is complicated and difficult to present such kind of data. Therefore, it is found to be more useful to study each crop separately as presented in Table 7.

Table 5: Average values of the soil content of nutrients

\begin{tabular}{|c|c|c|c|c|c|c|c|}
\hline $\begin{array}{l}\text { Parameter } \\
\text { Treatment }\end{array}$ & $\mathrm{N}$ & $\mathrm{P}$ & $\mathrm{K}$ & $\mathrm{Fe}$ & $\mathrm{Cu}$ & $\mathrm{Mn}$ & $\mathrm{Zn}$ \\
\hline $\mathrm{T}$ & $\begin{array}{l}170.50 \\
\pm 11.98\end{array}$ & $\begin{array}{c}4.39 \\
\pm 0.31\end{array}$ & $\begin{array}{c}111.80 \\
\pm 7.85\end{array}$ & $\begin{array}{c}2.05 \\
\pm 0.14\end{array}$ & $\begin{array}{c}0.73 \\
\pm 0.05\end{array}$ & $\begin{array}{c}2.41 \\
\pm 0.17\end{array}$ & $\begin{array}{c}0.78 \\
\pm 0.06\end{array}$ \\
\hline M & $\begin{array}{l}176.00 \\
\pm 12.36\end{array}$ & $\begin{array}{c}4.80 \\
\pm 0.34\end{array}$ & $\begin{array}{c}133.80 \\
\pm 9.40\end{array}$ & $\begin{array}{c}1.44 \\
\pm 0.10\end{array}$ & $\begin{array}{c}0.65 \\
\pm 0.05\end{array}$ & $1.07 \pm 0.08$ & $\begin{array}{r}0.66 \\
\pm 0.05\end{array}$ \\
\hline $\mathrm{S}$ & $\begin{array}{l}184.30 \\
\pm 12.94\end{array}$ & $\begin{array}{r}4.65 \\
\pm 0.33\end{array}$ & $\begin{array}{l}152.60 \\
\pm 10.72\end{array}$ & $\begin{array}{c}2.07 \\
\pm 0.15\end{array}$ & $\begin{array}{c}0.82 \\
\pm 0.06\end{array}$ & $\begin{array}{c}2.36 \\
\pm 0.17\end{array}$ & $\begin{array}{c}0.98 \\
\pm 0.07\end{array}$ \\
\hline$M \times S$ & $\begin{array}{c}180.55 \\
\pm 6.91\end{array}$ & $\begin{array}{c}4.74 \\
\pm 0.18\end{array}$ & $\begin{array}{c}135.95 \\
\pm 5.23\end{array}$ & $\begin{array}{c}1.96 \\
\pm 0.08\end{array}$ & $\begin{array}{c}0.76 \\
\pm 0.03\end{array}$ & $\begin{array}{c}2.15 \\
\pm 0.09\end{array}$ & $\begin{array}{r}0.75 \\
\pm 0.03\end{array}$ \\
\hline F-test for $\mathrm{M}$ & $*$ & NS & $* *$ & $* *$ & $* *$ & $* *$ & NS \\
\hline F-test for S & NS & NS & NS & NS & NS & NS & $* *$ \\
\hline F-test for $M \times S$ & NS & NS & * & $*$ & NS & $* *$ & $* *$ \\
\hline
\end{tabular}

Table 6: chemical analysis and average values of the irrigation water

\begin{tabular}{|c|c|c|c|c|c|c|c|c|c|}
\hline $\begin{array}{c}\text { Parameter } \\
\text { Treatment }\end{array}$ & $\mathrm{pH}$ & $\mathrm{EC}$ & $\mathrm{HCO}$ & $\mathrm{Cl}$ & $\mathrm{SO} 4$ & $\mathrm{Ca}$ & $\mathrm{Mg}$ & $\mathrm{Na}$ & $\mathrm{K}$ \\
\hline $\mathrm{T}$ & $\begin{array}{c}7.00 \\
\pm 0.13\end{array}$ & $\begin{array}{c}0.09 \\
\pm 0.00\end{array}$ & $\begin{array}{c}0.02 \\
\pm 0.00\end{array}$ & $\begin{array}{c}0.08 \\
\pm 0.00\end{array}$ & $\begin{array}{c}0.00 \\
\pm 0.00\end{array}$ & $\begin{array}{c}0.04 \\
\pm 0.00\end{array}$ & $\begin{array}{c}0.02 \\
\pm 0.00\end{array}$ & $\begin{array}{c}0.03 \\
\pm 0.00\end{array}$ & $\begin{array}{c}0.01 \\
\pm 0.000\end{array}$ \\
\hline $\mathrm{M}$ & $\begin{array}{c}7.3 \\
\pm 0.133\end{array}$ & $\begin{array}{c}0.08 \\
\pm 0.001\end{array}$ & $\begin{array}{c}0.01 \\
\pm 0.000\end{array}$ & $\begin{array}{c}0.08 \pm \\
0.001\end{array}$ & $\begin{array}{c}0.01 \\
\pm 0.00\end{array}$ & $\begin{array}{c}0.06 \\
\pm 0.001\end{array}$ & $\begin{array}{c}0.01 \\
\pm 0.000\end{array}$ & $\begin{array}{c}0.02 \\
\pm 0.000\end{array}$ & $\begin{array}{c}0.01 \\
\pm 0.000\end{array}$ \\
\hline $\mathrm{S}$ & $\begin{array}{c}6.80 \\
\pm 0.124\end{array}$ & $\begin{array}{c}9.10 \\
\pm 0.166\end{array}$ & $\begin{array}{c}0.04 \\
\pm 0.001\end{array}$ & $\begin{array}{c}94.30 \\
\pm 1.722\end{array}$ & $\begin{array}{c}0.80 \\
\pm 0.015\end{array}$ & $\begin{array}{c}0.07 \\
\pm 0.001\end{array}$ & $\begin{array}{c}0.05 \\
\pm 0.001\end{array}$ & $\begin{array}{c}95.00 \\
\pm 1.734\end{array}$ & $\begin{array}{c}0.02 \\
\pm 0.000\end{array}$ \\
\hline $\mathrm{M} \times \mathrm{S}$ & $\begin{array}{c}7.025 \\
\pm 0.070\end{array}$ & $\begin{array}{c}4.668 \\
\pm 0.030\end{array}$ & $\begin{array}{c}0.023 \\
\pm 0.065\end{array}$ & $\begin{array}{c}46.565 \\
\pm 0.000\end{array}$ & $\begin{array}{c}0.438 \\
\pm 0.654\end{array}$ & $\begin{array}{c}0.065 \pm \\
0.001\end{array}$ & $\begin{array}{c}0.030 \pm \\
0.000\end{array}$ & $\begin{array}{c}46.913 \\
\pm 0.660\end{array}$ & $\begin{array}{c}0.018 \\
\pm 0.000\end{array}$ \\
\hline F-test for M & $* *$ & $*$ & $* *$ & $\mathrm{NS}$ & $* *$ & $* *$ & $* *$ & $\mathrm{NS}$ & $* *$ \\
\hline F-test for S & $* *$ & $* *$ & $* *$ & $* *$ & $* *$ & $* *$ & $* *$ & $* *$ & $* *$ \\
\hline F-test for M $\times \mathrm{S}$ & $\mathrm{NS}$ & $*$ & $* *$ & $\mathrm{NS}$ & $* *$ & $\mathrm{NS}$ & $\mathrm{NS}$ & $\mathrm{NS}$ & $* *$ \\
\hline
\end{tabular}


Table 7: Statistical analysis of FW and DW of wheat and barley

\begin{tabular}{|c|c|c|c|c|c|c|c|c|}
\hline \multirow{2}{*}{$\begin{array}{c}\text { Parameter } \\
\text { Treatment }\end{array}$} & \multicolumn{5}{|c|}{ Barley } & \multicolumn{5}{c|}{ Wheat } \\
\cline { 2 - 10 } & $\mathrm{FW}$ & F-test & DW & F-test & FW & F-test & DW & F-test \\
\hline $\mathrm{T}$ & $1.13 \pm 0.80$ & & $0.23 \pm 0.14$ & & $0.95 \pm 0.29$ & & $0.28 \pm 0.08$ & \\
\hline $\mathrm{M}$ & $1.36 \pm 0.46$ & $\mathrm{NS}$ & $0.29 \pm 0.07$ & $* *$ & $1.43 \pm 0.24$ & $* *$ & $0.39 \pm 0.07$ & $* *$ \\
\hline $\mathrm{S}$ & $0.78 \pm 0.17$ & $*$ & $0.14 \pm 0.04$ & $* *$ & $0.51 \pm 0.15$ & $* *$ & $0.14 \pm 0.04$ & $* *$ \\
\hline $\mathrm{M} \times \mathrm{S}$ & $1.08 \pm 0.50$ & $\mathrm{NS}$ & $0.22 \pm 0.10$ & $\mathrm{NS}$ & $0.91 \pm 0.40$ & $\mathrm{NS}$ & $0.26 \pm 0.11$ & $\mathrm{NS}$ \\
\hline
\end{tabular}

Data in Table 7 showed significant beneficial effect of magnetization of irrigation water on FW and DW of wheat. Only DW of barley is significantly affected by magnetized water. Such result may be related to the high water percent in pant relative to dry mass. On the other hand, salinity significantly decreased both FW and DW of both barley and wheat. Wheat gives higher FW and DW when non-saline water was used in irrigation regardless magnetization. Opposite trend was observed with saline water, which indicate that barley was more tolerant to salinity than wheat. No significant effect was indicated, of magnetization and salinity interaction Only DW of wheat and barley was considered and presented in Fig $3 \mathrm{a}$ and $\mathrm{b}$ because it is showed significant difference of all treatments and because DW is more reliable in evaluating the reflection effect of magnetization and salinity.

The obtained result is somehow, agree with what mentioned by ljaz et al. (2012) and Omran et al. (2014) recommends the use of magnetized water for the purpose of germination enhancement of barley and wheat seeds. Sadeghipour and Aghaei (2013) reported that: the impact of magnetic water increased root growth and stomata conductance, which increase absorption and assimilation of nutrients. Selim and El-Nady 2011 found that magnetically treated water improves tomato growth and yield. The explanation could be excluded from some auteurs (Goodman et al. 1995 and Atak et al. 2003), who concluded that the enhancing effects of magnetized water were due to that magnetic field changes the characteristics of cell membrane, gene expression, protein biosynthesis and enzyme activities. Moreover, the presence of paramagnetic properties in chloroplast can cause an acceleration of seeds metabolism by magnetic treatment (Aladjadjiyan and Ylieve 2003).

\section{4-2 Effect of magnetization and salinity of irrigation water on plant nutrient content}

Data presented in Table 8 and Fig 4 a and $b$ evidently proves significant increase content of all studied nutrients, while significant decrease was observed with salinity in wheat crop. Similar trend was found with barley crop, with exception of non-significant effect of magnetization on $\mathrm{N}$, salinity on $\mathrm{Mn}$, and of their interaction on $\mathrm{Fe}$. Moreover, significant improve with the interaction. The obtained results, obviously deduct that magnetism improve plant uptake of both macronutrients and micronutrients of both studied crops and under non-stress and stress of salinity. 


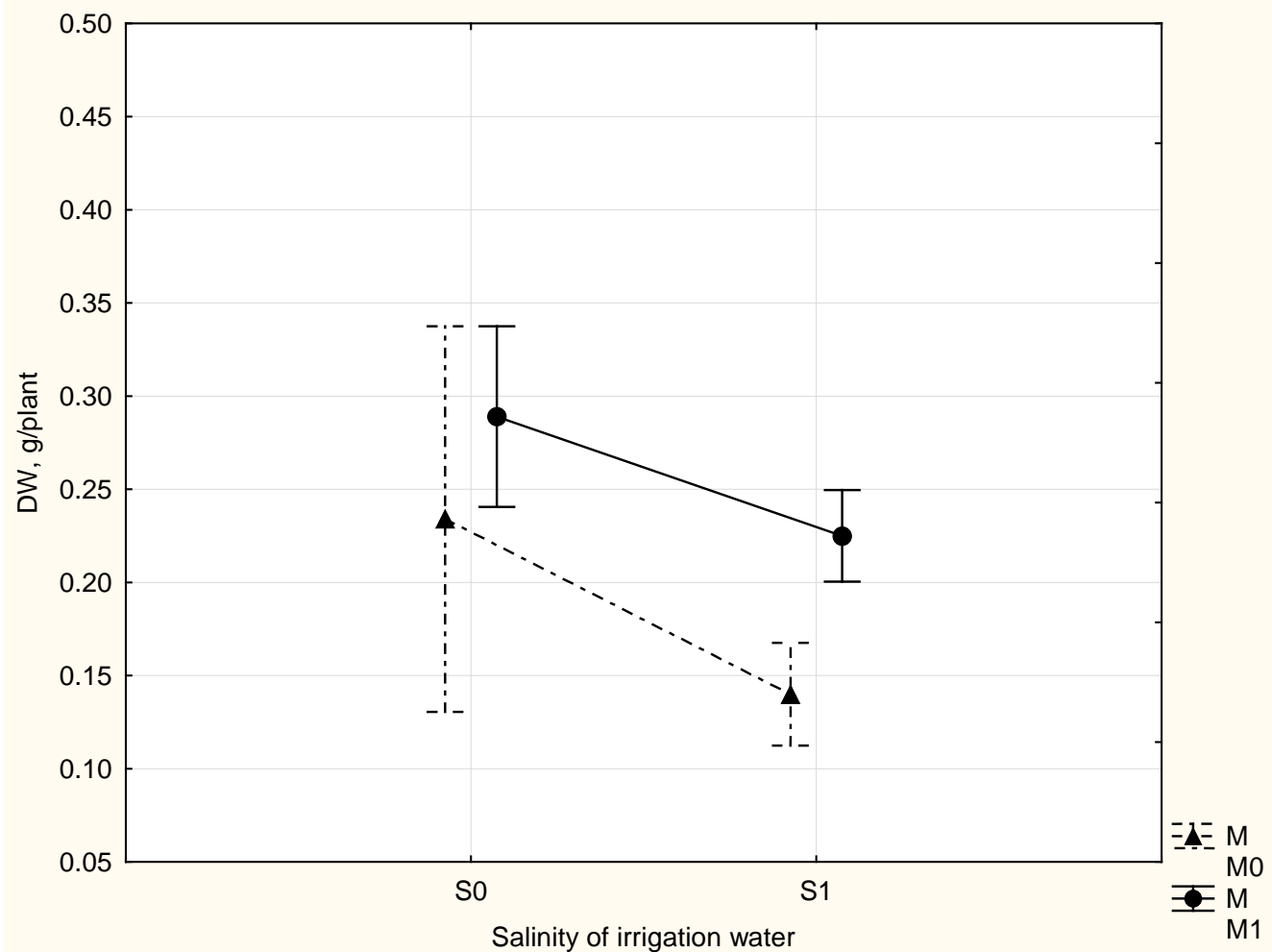

Fig 3 a: Effect of magnetization and salinity of irrigation water on DW of barley

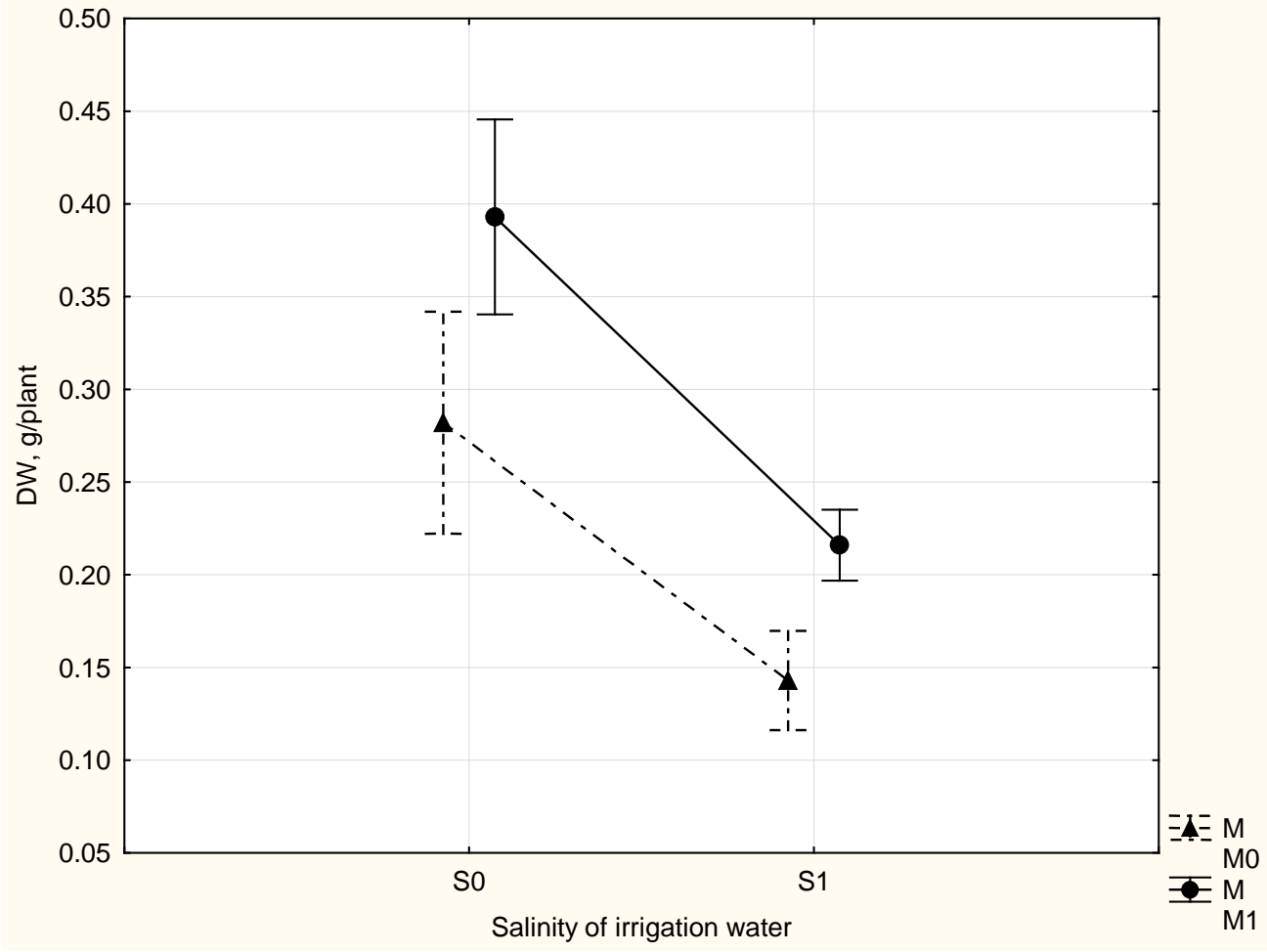

Fig 3 b: Effect of magnetization and salinity of irrigation water on DW of wheat 
Table 8: Effect of magnetization and salinity on plant nutrient content

\begin{tabular}{|c|c|c|c|c|c|c|c|c|}
\hline \multicolumn{2}{|c|}{$\begin{array}{l}\text { Parameter- } \\
\text { Treatment }\end{array}$} & $\mathrm{N}$ & $P$ & $\mathrm{~K}$ & $\mathrm{Fe}$ & $\mathrm{Cu}$ & $\mathrm{Mn}$ & $\mathrm{Zn}$ \\
\hline \multirow{7}{*}{ 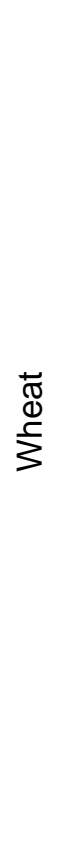 } & $\mathrm{T}$ & $\begin{array}{c}3.78 \\
\pm 0.17\end{array}$ & $\begin{array}{r}0.40 \\
\pm 0.02\end{array}$ & $\begin{array}{c}4.09 \\
\pm 0.18\end{array}$ & $\begin{array}{l}95.00 \\
\pm 4.18\end{array}$ & $\begin{array}{l}17.00 \\
\pm 0.75\end{array}$ & $\begin{array}{l}66.00 \\
\pm 2.90\end{array}$ & $\begin{array}{l}47.00 \\
\pm 2.07\end{array}$ \\
\hline & M & $\begin{array}{c}4.05 \\
\pm 0.18\end{array}$ & $\begin{array}{c}0.44 \\
\pm 0.02\end{array}$ & $\begin{array}{c}4.19 \\
\pm 0.18\end{array}$ & $\begin{array}{c}113.00 \\
\pm 4.97\end{array}$ & $\begin{array}{r}19.0 \\
\pm 0.84\end{array}$ & $\begin{array}{l}67.00 \\
\pm 2.95\end{array}$ & $\begin{array}{l}41.00 \\
\pm 1.80\end{array}$ \\
\hline & $\mathrm{S}$ & $\begin{array}{c}2.42 \\
\pm 0.11\end{array}$ & $\begin{array}{r}0.40 \\
\pm 0.02\end{array}$ & $\begin{array}{r}2.06 \\
\pm 0.09\end{array}$ & $\begin{array}{l}78.00 \\
\pm 3.43\end{array}$ & $\begin{array}{l}16.00 \\
\pm 0.70\end{array}$ & $\begin{array}{l}56.00 \\
\pm 2.46\end{array}$ & $\begin{array}{l}34.00 \\
\pm 1.49\end{array}$ \\
\hline & $M \times S$ & $\begin{array}{c}3.32 \\
\pm 0.08\end{array}$ & $\begin{array}{r}0.40 \\
\pm 0.01\end{array}$ & $\begin{array}{c}2.96 \\
\pm 0.08\end{array}$ & $\begin{array}{l}94.25 \\
\pm 2.28\end{array}$ & $\begin{array}{l}15.50 \\
\pm 0.38\end{array}$ & $\begin{array}{l}63.75 \\
\pm 1.53\end{array}$ & $\begin{array}{l}41.25 \\
\pm 0.99\end{array}$ \\
\hline & $\begin{array}{c}\text { F-test for } \\
M\end{array}$ & $\star *$ & $\star \star$ & $\star \star$ & $\star \star$ & $\star \star$ & $\star \star$ & $\star \star$ \\
\hline & $\begin{array}{c}\text { F-test for } \\
\mathrm{S}\end{array}$ & $\star *$ & $\star *$ & $\star *$ & $\star \star$ & $\star *$ & $\star \star$ & $\star *$ \\
\hline & $\begin{array}{c}\text { F-test for } \\
M \times S\end{array}$ & $\star \star$ & $\star \star$ & $\star \star$ & $\star \star$ & $\star \star$ & $\star \star$ & $\star \star$ \\
\hline \multirow{7}{*}{$\frac{\frac{\lambda}{\bar{\varpi}}}{\frac{\nabla}{\infty}}$} & $\mathrm{T}$ & $\begin{array}{c}3.61 \\
\pm 0.16\end{array}$ & $\begin{array}{c}0.40 \\
\pm 0.02\end{array}$ & $\begin{array}{c}3.61 \\
\pm 0.16\end{array}$ & $\begin{array}{l}98.00 \\
\pm 4.31\end{array}$ & $\begin{array}{l}20.00 \\
\pm 0.88\end{array}$ & $\begin{array}{l}59.00 \\
\pm 2.59\end{array}$ & $\begin{array}{l}54.00 \\
\pm 2.37\end{array}$ \\
\hline & $M$ & $\begin{array}{c}3.67 \\
\pm 0.16\end{array}$ & $\begin{array}{r}0.50 \\
\pm 0.02\end{array}$ & $\begin{array}{c}4.00 \\
\pm 0.18\end{array}$ & $\begin{array}{c}118.00 \\
\pm 5.19\end{array}$ & $\begin{array}{l}11.00 \\
\pm 0.48\end{array}$ & $\begin{array}{l}63.00 \\
\pm 2.77\end{array}$ & $\begin{array}{l}58.00 \\
\pm 2.55\end{array}$ \\
\hline & $\mathrm{S}$ & $\begin{array}{c}2.90 \\
\pm 0.13\end{array}$ & $\begin{array}{r}0.50 \\
\pm 0.02\end{array}$ & $\begin{array}{c}2.84 \\
\pm 0.12\end{array}$ & $\begin{array}{l}84.00 \\
\pm 3.69\end{array}$ & $\begin{array}{l}11.00 \\
\pm 0.48\end{array}$ & $\begin{array}{l}52.00 \\
\pm 2.29\end{array}$ & $\begin{array}{l}42.00 \\
\pm 1.85\end{array}$ \\
\hline & $M \times S$ & $\begin{array}{c}3.18 \\
\pm 0.08\end{array}$ & $\begin{array}{c}0.48 \\
\pm 0.01\end{array}$ & $\begin{array}{c}2.96 \\
\pm 0.07\end{array}$ & $\begin{array}{c}102.50 \\
\pm 2.47\end{array}$ & $\begin{array}{l}15.00 \\
\pm 0.37\end{array}$ & $\begin{array}{l}61.00 \\
\pm 1.47\end{array}$ & $\begin{array}{l}54.00 \\
\pm 1.31\end{array}$ \\
\hline & $\begin{array}{c}\text { F-test for } \\
M\end{array}$ & NS & $\star *$ & $\star \star$ & $\star \star$ & * & $\star \star$ & $\star \star$ \\
\hline & $\begin{array}{c}\text { F-test for } \\
\mathrm{S}\end{array}$ & ** & $\star *$ & $\star *$ & $\star \star$ & * & NS & ** \\
\hline & $\begin{array}{c}\text { F-test for } \\
M \times S\end{array}$ & * & $\star *$ & $\star *$ & NS & $\star \star$ & $\star \star$ & $\star \star$ \\
\hline
\end{tabular}




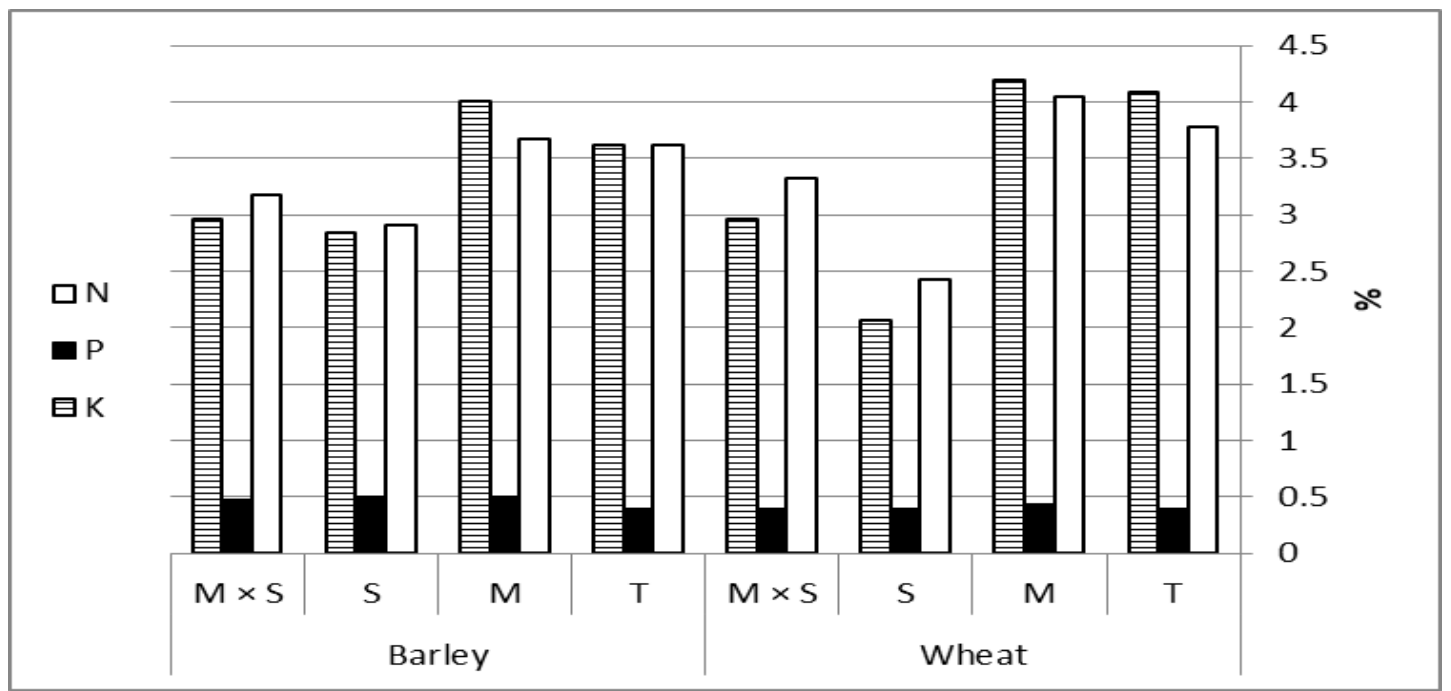

Fig 4 a: Effect of magnetization and salinity of irrigation water on the content of macronutrient of barley and wheat plants

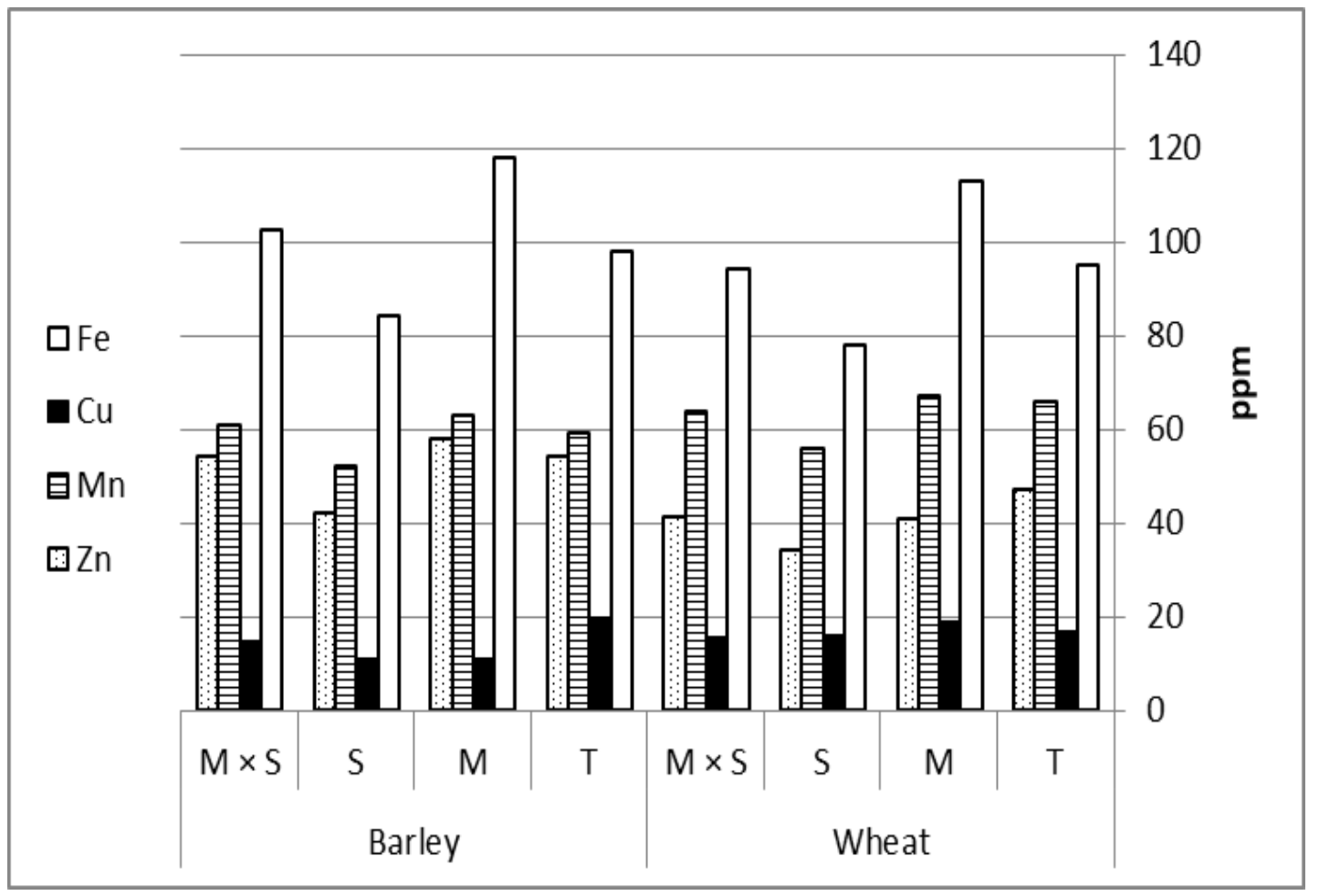

Fig 4 b: Effect of magnetization and salinity of irrigation water on the content of micronutrient of barley and wheat plants

\section{Conclusion}

Based on the obtained results, it could be concluded that:

1- Magnetized water improved physical and chemical properties of soil and irrigation water.
2- Magnetized water improved plant growth (fresh and dry weight) of both barley and wheat in both cases of using non-saline and saline irrigation water. 
3- Magnetized water enhanced plant nutrients content of both barley and wheat plants.

4- High salinity of irrigation water had harmful effect on soil properties and on plant growth and nutrients content.

5- Magnetized water reduced the harmful impact of salinity on both barley and wheat.

6- The study recommended magnetically treated water to be used in irrigating barley and wheat grown in sandy soil under saline and non-saline irrigation water.

7- Further studies are required in open field to clarify, evaluate and validate the effect of magnetized water on crop yield (quantity and quality) in different types of soil and crops under different levels of salinity and magnetization.

\section{REFERENCES}

Aladjadjiyan, A. (2002). Study of the Influence of Magnetic Field on Some Biological Characteristics of Zea mais. J. Central Europ. Agric. 3: 89-94.

Aladjadjiyan, A. and T. Ylieva (2003). Influence of stationary magnetic field on the early stages of the development of tobacco seeds (Nicotiana tabacum L.). J. of Central Europ. Agric. 4: 131-138.

Alexander MP, Doijode SD (1995). Electromagnetic field, a novel tool to increase germination and seedling vigour of conserved onion (Allium cepa L.) and rice (Oryza sativa L.) seeds with low viability. Plant Genetic Resources Newsletter. 104: 1-5.

Atak, C., O. Emiroglu, S. Aklimanoglu and A. Rzakoulieva (2003). Stimulation of regeneration by magnetic field in soybean (Glycine max L. Merrill) tissue cultures. J. Cell Mol. Biol. 2:113-119.

Black, G. A., D.D. Evans, J.L. Hite, L.E. Ensminger and F.E. Clerk (1965). Methods of soil analysis. Part 1 and 2 . Am. Soc. Agron. Madison, USA.

Cakmak, I., R. Dumlupinar and S. Erdal (2009). Acceleration and early growth of wheat and bean seedlings grown under various magnetic field and osmotic conditions. Bioelectromagnetics 31: 120129.

Carbonell, M.V., E. Martinez and J.M. Amaya (2000). Stimulation of germination in rice (Oryza sativa L.) by a static magnetic field. Electro-Magnetobiol. 19: 121-128.

Gholami, A. and S. Sharafi (2010). Effect of magnetic field on seed germination of two wheat cultivars. World Acad. Sci. Eng. Technol., 62: 279-282.

Goodman, E.M., B. Greenabaum and T.M. Morron (1995). Effects of electromagnetic fields on molecules and cells. International Review of Cytology 158: 279-325.

Grewal, H.S. and B.L. Maheshwari (2011). Magnetic treatment of irrigation water and Snow Pea and Chickpea Seeds Enhances Early Growth and Nutrient Contents of Seedlings. Bioelectromagnetics 32: 58-65.

Hachicha, M., B. Kahlaoui, N. Khamassi, E. Misle and O. Jouzdan (2016). Effect of electromagnetic treatment of saline water on soil and crops. J. Saudi Society Agrc. Sci. In press. (http://www.sciencedirect.com/science/art icle/pii/S1658077X16000023\#b0005)

ljaz1, B., S. Ahmad, D. Ahmad, M. Masood and S. Siddiqui (2012). Changes in germination behavior of wheat seeds exposed to magnetic field and magnetically structured water. African Journal of Biotechnology 11(15): 35753582.

Lihua, X. and G. Jixun (2001). Effect of magnetic seed treatment on growth and saline-alkali tolerance of Leymus chinensis. Acta Prataculturae Sinica. 10: 58-63 (c.f. Cab. Abst. 2002-2003).

Maheshwari, B.L. and H.S. Grewal (2009). Magnetic treatment of irrigation water: Its effects on vegetable crop yield and water productivity. Agricultural Water Management 96: 1229-1236. 
Mahmoud, R.A., K.T. Asmael and J.G. Lafta (2011). Effect of Magnetic Treatment of water for irrigation and seed Qualities of the Plant vegetative growth corundum of oriandrum sativum. Bagdad Sci. J. 8(4): 891-895.

Omran, W.M., M.M.F. Mansour and K.A. Fayez (2014). Magnetized water improved germination, growth and tolerance to salinity of cereal crops. IJAR 2(5): 301-308.

Rashidi, S., A. Yadollahpour, S. Shirali and G. Rajashekar (2016). Magnetized water treatment: Reviewing the environmental applications. IJPT 8(1): 11431-11441.

Ryan, J., G. Estefan and Abdul Rashid (2001). Soil and Plant Analysis
Laboratory Manual. $2^{\text {nd }}$ ed. ICARDA (ISBN 92-9127-118-7), Syria.

Sadeghipour and Aghaei P (2013). Improving the growth of cowpea (Vigna unguiculata L. Walp.) by magnetized water. J. Biodiversity and Environmental Sci. (3)1: 37-43.

Selim, A.H. and M.F. El-Nady (2011). Physio-anatomical responses of drought stressed tomato plants to magnetic field. Acta Astronautica 69(7):387-396.

Surendran, U., O. Sandeep and J. Joseph (2016). The impacts of magnetic treatment of irrigation water on plant, water and soil characteristics. Agricultural Water Management 178:21-29. 
تأثير مغنطة وملوحة ماء الري علي بعض خواص التربة ونمو القمح والثعير

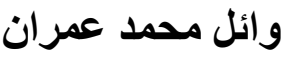

قسم علوم الأراضى - كلية الزراعة - جامعة المنوفية

بسبب نقص ألماء عالي الصداحية المتاح للري خصوصا في الأراضي الصحر اوية ، ونظرا للأهمية الاقتصادية

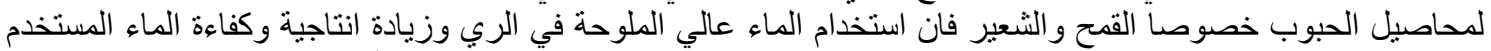

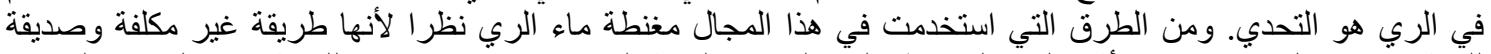

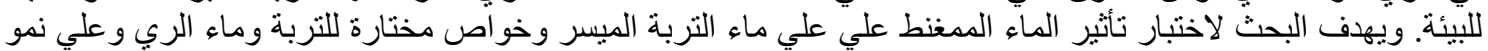

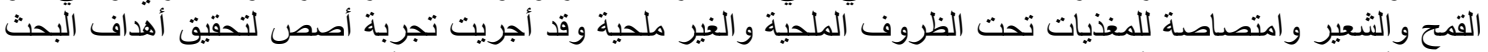

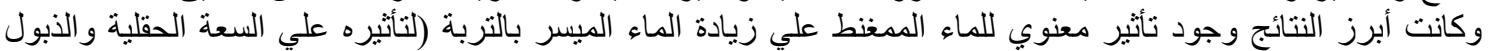

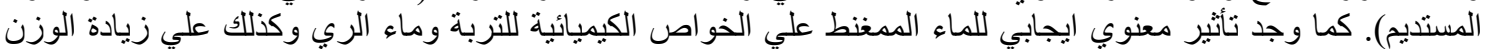

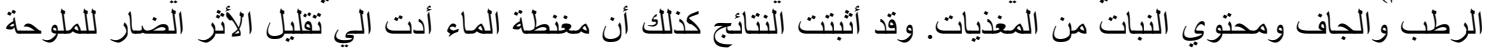

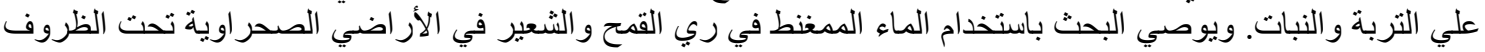

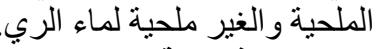

الكلمات الافتتاحية: الماء الممغنط ـ ملوحة ماء الري ـ الماء الميسر للامنصاص ـ العناصر المغذية ـ نمو القمح والثعبر. 